Supardi, Anik Widiastuti

\title{
PEMANFAATAN LABORATORIUM IPS SMP
}

\author{
Supardi \\ Anik Widiastuti
}

Pendidikan IPS Fakultas Ilmu Sosial UNY

Email : pardi_uny@yahoo.com, Hp. 081226916503

\begin{abstract}
Abstrak
Penelitian ini bertujuan mengetahui pemanfaatan laboratorium IPS di SMP. Pemanfaatan laboratorium dalam penelitian ini ditinjau dari; 1) kondisi laboratorium IPS di SMP, 2) manajemen laboratorium IPS di SMP, 3) peran kepala sekolah dalam pemanfaatan laboratorium IPS, 4) strategi guru dalam pemanfaatan laboratorium IPS, 5) pemanfaatan laboratorium IPS bagi para siswa. Jenis penelitian ini adalah penelitian kualitatif. Penelitian ini dilaksanakan di SMP 1 Bantul, SMP 19 Purworejo dan SMP IT Darul Hikmah Pakem pada bulan Oktober sampai dengan November 2012. Data diperoleh dengan teknik wawancara, observasi dan dokumentasi menggunakan pedoman wawancara dan lembar observasi. Hasil penelitian menunjukkan bahwa: 1) kondisi laboratorium IPS di tiga sekolah yang diteliti pada dasarnya telah memenuhi syarat minimal laboratorium, hanya saja ketersediaan perangkat lain masih kurang lengkap, 2) manajemen laboratorium IPS didasarkan pada pengelompokkan subjek atau konsep ilmu-ilmu sosial serta penggunaannya telah diatur sehingga memungkinkan pemanfaatan laboratorium secara teratur dan tidak terjadi benturan jadwal antar guru, 3) kepala sekolah mulai menyadari pentingnya laboratorium IPS dalam mendukung kualitas pembelajaran di SMP, sehingga mereka mulai memperhatikan keberadaan laboratorium IPS dengan dukungan kebijakan pengembangan laboratorium IPS, 4) Para guru merasakan pentingnya keberadaan laboratorium IPS, dan mereka telah berupaya melakukan pemanfaatan laboratorium IPS dalam mendukung pembelajaran IPS namun belum optimal disebabkan oleh terbatasnya sumber daya yang menangani, belum optimalnya dukungan finansial untuk mengembangkan laboratorium IPS, dan pada kenyataannya bahwa keberadaan laboratorium IPS di SMP masih merupakan hal baru dalam praksis pendidikan IPS di sekolah, 5) Para siswa merasa sangat terbantu dengan adanya laboratorium IPS di sekolah, karena pembelajaran menjadi lebih mudah dan menyenangkan.
\end{abstract}

Kata Kunci: pemanfaatan, laboratorium IPS 


\begin{abstract}
This study aims to examine the use of social studies in junior high school laboratory. Laboratory utilization in this study in terms of: 1 ) social studies in junior high school laboratory conditions, 2 ) the laboratory management in junior high school social studies, 3 ) the role of the principal in the IPS laboratory utilization, 4) strategies of teachers in the use of laboratory IPS, 5 ) for the IPS laboratory utilization students. This research is qualitative research. This research was carried out in 1 Bantul SMP, SMP 19 and SMP IT Purworejo Pakem Darul Hikmah in October to November 2012. Data obtained by interview, observation and documentation using interview guides and observation sheets. The results showed that:1) IPS laboratory conditions at three schools studied had essentially minimally qualified laboratories, and the availability of other devices of still not complete, 2) IPS laboratory management based on the concept of grouping subjects or social sciences as well as its use has been arranged so as to allow the use of the lab on a regular basis and not a clash between teachers' schedules, 3 ) the principal began to realize the importance of the laboratory in support of the quality of teaching social studies in junior high, so they began to notice the existence of laboratories IPS with IPS policy support laboratory development, 4) the teachers feel importance of the IPS laboratory, and they have attempted to do the IPS laboratory utilization in support of social studies learning but not optimal due to the limited resources that deal, not optimal financial support to develop the IPS laboratory, and the fact that the existence of social studies in middle school lab is still a novelty in praxis social studies education in schools, 5) the student was greatly assisted by the IPS lab at school, because learning becomes easier and fun.
\end{abstract}

Keywords : utilization, IPS laboratory

\title{
Pendahuluan
}

IPS merupakan mata pelajaran pada jenjang pendidikan di tingkat sekolah, yang dikembangkan secara terintegrasi dengan mengambil konsep-konsep esensial dari Ilmu-ilmu Sosial dan humaniora. IPS mengkaji berbagai fenomena kehidupan dan masalah sosial yang diorganisasikan dan disajikan secara ilmiahpedagogis dan psikologis, yang telah disederhanakan, diseleksi, dan diadaptasi untuk kepentingan pencapaian tujuan pendidikan. Melalui mata pelajaran IPS, peserta didik diarahkan untuk dapat 
menjadi warga negara Indonesia yang demokratis, dan bertanggung jawab, serta warga dunia yang cinta damai.

Pendidikan IPS untuk tingkat sekolah bisa diartikan sebagai: (1) Pendidikan IPS yang menekankan pada tumbuhnya nilai-nilai kewarganegaraan, moral ideologi negara dan agama; Pendidikan IPS yang menekankan pada isi dan metode berpikir ilmuan sosial; (3) pendidikan IPS yang menekankan pada reflective inquiry; dan (4) Pendidikan IPS yang mengambil kebaikankebaikan dari butir 1, 2, 3, di atas" (Muhammad Numan Somantri, 2001: 44). Melihat pendapat di atas maka diperlukan adanya laboratorium IPS untuk menunjang keterlaksanaan metode berpikir ilmuwan sosial dan juga keterlaksanaan reflective inquiry.

Dalam pembelajaran IPS, laboratorium digunakan sebagai sarana belajar. Kenyataannya, keberadaan laboratorium IPS di SMP masih sangat minim, berbeda dengan laboratorium IPA. Kebanyakan sekolah hanya mengembangkan laboratorium IPA akan tetapi banyak sekolah yang tidak memiliki laboratorium IPS. Menurut Mustafawan (2012), Laboratorium adalah suatu tempat yang digunakan untuk melakukan percobaan maupun pelatihan yang berhubungan dengan ilmu fisika, biologi, dan kimia atau bidang ilmu lain, yang merupakan suatu ruangan tertutup, kamar atau ruangan terbuka seperti kebun dan lain-lain. Melihat pendapat di atas, laboratorium dapat digunakan dalam berbagai ilmu, dalam hal ini termasuk IPS. Laboratorium IPS merupakan tempat yang disiapkan secara khusus untuk melakukan kegiatan eksperimen, analisis, observasi, penelitian dan kegiatan pembelajaran Ilmu Pengetahuan Sosial (IPS). Pengertian tempat ini bisa dalam pengertian indoor maupun outdoor. Laboratorium IPS memiliki fungsi sebagai tempat berlangsungnya kegiatan 
pembelajaran IPS secara praktek dengan peralatan khusus yang tidak mudah dihadirkan di ruang kelas.

\section{Laboratorium IPS}

Menurut Purwanti Elly dan Mahmudati Nurul 2002, keberadaan Laboratorium untuk suatu sekolah atau pun Perguruan Tinggi adalah sangat penting. Keberadaan laboratorium merupakan tuntutan seiring dengan perkembangan dalam pengajaran dan pengembangan kurikulum yang menuntut mahasiswa aktif untuk melakukan kegiatan. Laboratorium harus menunjang kegiatan-kegiatan yang berpusat pada pengembangan ketrampilan tertentu antara lain ketrampilan proses, ketrampilan motorik dan pembentukan sikap ilmiah, khususnya pengembangan minat untuk melakukan penyelidikan, penelitianpenelitian lingkungan dan minat untuk mempelajari alam secara mendalam (http://www.majalahpendidikan.com).

Menurut Sukarso (2005), secara garis besar laboratorium dalam proses pendidikan adalah sebagai berikut:

1. Sebagai tempat untuk berlatih mengembangkan (skill) keterampilan intelektual melalui kegiatan pengamatan, pencatatan dan pengkaji gejala-gejala alam.

2. Mengembangkan keterampilan motorik siswa. Siswa akan bertambah keterampila dalam mempergunakan alat-alat media yang tersedia untuk mencari dan menemukan kebenaran.

3. Memberikan dan memupuk keberanian untuk mencari hakekat kebenaran ilmiah dari sesuatu objek dalam lingkungn alam dan sosial.

4. Memupuk rasa ingin tahu siswa sebagai modal sikap ilmiah seseorang calon ilmuan. 
5. Membina rasa percaya diri sebagai akibat keterampilan dan pengetahuan atau penemuan yang diperolehnya. (Mustafawan, 2012).

Dalam Standar Nasional Pendidikan pada Standar Sarana dan Prasarana tidak disebutkan adanya laboratorium IPS sebagai syarat minimal pelayanan pembelajaran di sekolah. Kesan dari perangkat hukum ini adalah seolah-olah Lab IPS tidak begitu penting di sekolah. Karena itulah tidak heran apabila pemerintah selalu pelaksana amanat perundangan kurang memperhatikan keberadaan laboratorium IPS.

Walaupun tidak ada ketentuan sekolah harus memiliki laboratorium IPS, namun secara kreatif dan inovatif beberapa sekolah mencoba mengembangkan laboratorium IPS secara mandiri. Para guru semakin banyak yang sadar pentingnya laboratorium IPS untuk mengembangkan laboratorium IPS menjadi lebih menarik dan berkualitas. Memang dalam pelaksanaanya pengembangan laboratorium IPS di beberapa sekolah masih menghadapi banyak kendala baik yang telah mendirikan laboratorium IPS maupun yang baru merintisnya. Sebagian permasalahan misalnya bahwa sekolah-sekolah belum memiliki tenaga khusus atau laboran bagi laboratorium IPS. Laboran sebagai pengelola sekaligus tenaga yang merawat laboratorium masih belum ada. Sebagai aset pendidikan yang sangat penting, idealnya laboratorium menjadi tumpuan sekolahsekolah sebagai arena pembelajaran. Pembelajaran IPS dengan memanfaatkan laboratorium akan mempermudah siswa mengkunstruk konsep dan memahami materi yang diajarkan.

Keberadaan laboratorium IPS yang masih relatif baru dikembangkan tersebut menarik untuk dikaji sehingga dapat menjadi referensi tahap pengembangan berikutnya. Beberapa 
sekolah di DIY dan Jateng terdata telah memiliki laboratorium IPS. Hal ini cukup menarik untuk diteliti, karena laboratorium IPS yang rata-rata sudah dikembangkan 2 tahun tersebut disinyalir mampu meningkatkan kualitas pembelajaran IPS di sekolah.

Berdasarkan latar belakang masalah di atas, maka peneliti mengajukan perumusan masalah sebagai berikut:

1. Bagaimana kondisi laboratorium IPS di SMP?

2. Bagaimana manajemen laboratorium IPS di SMP?

3. Bagaimana peran kepala sekolah dalam pemanfaatan laboratorium IPS di SMP?

4. Bagaimana strategi pemanfatan laboratorium IPS oleh para guru IPS di SMP?

5. Bagaimana pemanfaatan laboratorium IPS di SMP bagi para siswa?

\section{Metode Penelitian}

Jenis penelitian yang digunakan dalam penelitian ini adalah penelitian eksploratif. Strategi penelitiannya menggunakan pendekatan kualitatif dengan jenis analisis deskriptif. Dengan penelitian ini diharapkan dapat menggali berbagai informasi mengenai keoptimalan pemanfaatan laboratorium IPS SMP secara deskriptif dan disajikan dalam bentuk data kualitatif.

Penelitian ini dilakukan di SMP Negeri 1 Bantul mewakili SMP di Yogyakarta, SMP 19 Purworejo mewakili SMP di Purworejo, dan SMP Darul Hikmah Pakem mewakili SMP swasta yang telah memiliki dan memanfaatkan laboratorium IPS dalam pembelajaran IPS. Penelitian dilaksanakan pada bulan Oktober sampai dengan bulan November 2012. Dalam penelitian ini peneliti mengumpulkan data dengan cara: 1) Observasi dan wawancara, lembar observasi dan pedoman wawancara ditujukan untuk mengumpulkan data tentang pemanfaatan laboratorium yang 
digali dengan sumber data dari guru, kepala sekolah dan siswa di sekolah yang menjadi lokasi penelitian sehingga dapat diperoleh data yang sebenarnya yang berkaitan dengan pemanfaatan laboratorium IPS SMP, 2) Dokumentasi, teknik dokumentasi dalam penelitian ini digunakan untuk memperoleh data bukti-bukti pemanfaatan laboratorium IPS SMP seperti program kerja, susunan pengurus, jadwal penggunaan, arsip isi, dan sebagainya.

Instrumen yang digunakan dalam penelitian ini berupa pedoman wawancara dan lembar observasi. Pedoman wawancara ditujukan kepada kepala sekolah sebagai penentu kebijakan di sekolah yang bersangkutan, guru sebagai pelaksana pembelajaran IPS dan siswa sebagai pemberi respon atas pembelajaran IPS yang dilaksanakan guru. Lembar observasi digunakan untuk menggali data tentang koleksi laboratorium, ketersediaan fasilitas pendukung laboratorium seperti air, listrik, internet serta untuk mengetahui pemakaian laboratorium IPS dalam pembelajaran IPS. Selain itu untuk pengumpulan data digunakan check list dokumentasi yang diisi sendiri oleh peneliti.

Teknik analisis data pada penelitian menggunakan analisis kualitatif dilakukan dengan cara penelitia merefleksi hasil observasi terhadap proses pembelajaran yang dilaksanakan oleh peneliti mengenai pemanfaatan laboratorium IPS SMP. Data yang berupa kata-kata dari catatan lapangan diolah menjadi kalimatkalimat yang bermakna dan dianalisis secara kualitatif. Teknik analisis kualitatif mengacu pada metode analisis dari Miles \& Huberman (Sugiyono, 2011) yang dilakukan dalam tiga komponen yang berurutan yaitu reduksi data, penyajian data dan penarikan kesimpulan. 


\section{Hasil Penelitian}

\section{Ketersediaan Laboratorium IPS di SMP}

a. Ketersediaan Ruangan

Syarat minimal laboratorium $7 \mathrm{~m} \times 7 \mathrm{~m}$ di tiga sekolah yang diteliti pada dasarnya sudah terpenuhi. Hanya saja ketersediaan perangkat lain yang seharusnya ada dalam Lab IPS masih kurang lengkap. Sebagai keterangan dapat dilihat dalam tabel berikut ini.

Tabel 1. Kondisi ketersediaan sarana dalam Lab IPS

\begin{tabular}{|c|c|c|c|c|}
\hline \multirow[t]{2}{*}{ No } & \multirow[t]{2}{*}{ Ketersediaan Sarana } & \begin{tabular}{|l|} 
SMP N 1 \\
Bantul
\end{tabular} & $\begin{array}{l}\text { SMP Darul } \\
\text { Hikmah Pakem }\end{array}$ & $\begin{array}{l}\text { SMP N } 19 \\
\text { Purworejo }\end{array}$ \\
\hline & & Skor & Skor & Skor \\
\hline 1 & Perabot & 2 & 2 & 2 \\
\hline \multirow[t]{2}{*}{2} & $\begin{array}{ll}\begin{array}{l}\text { Alat } \\
\text { pendidikan }\end{array} & \text { peraga } \\
\end{array}$ & 3 & 2 & 2 \\
\hline & Perkakas & 2 & 2 & 3 \\
\hline 3 & $\begin{array}{l}\text { Kotak PPPK beserta } \\
\text { isinya }\end{array}$ & 4 & 4 & 3 \\
\hline 4 & $\begin{array}{l}\text { Alat } \\
\text { kebakaran }\end{array}$ & 0 & 0 & 0 \\
\hline 5 & Alat pembersih & 3 & 3 & 4 \\
\hline 6 & Kumpulan buku & 2 & 2 & 2 \\
\hline 7 & Ruang persiapan & 0 & 0 & 0 \\
\hline 8 & Ruang penyimpanan & 2 & 1 & 2 \\
\hline 9 & Ruang praktikum & 1 & 1 & 1 \\
\hline 10 & Listrik & 3 & 3 & 2 \\
\hline 11 & LAN & 2 & 1 & 2 \\
\hline 12 & Sistem audio visual & 2 & 2 & 1 \\
\hline 13 & Instalasi air & 1 & 1 & 1 \\
\hline \multicolumn{2}{|c|}{$\begin{array}{l}\text { Total Skor (Skor maksimal } \\
=60 \text { ) }\end{array}$} & 27 & 24 & 25 \\
\hline \multicolumn{2}{|c|}{ Nilai (Nilai tertinggi = 100) } & 45 & 40 & 41,5 \\
\hline
\end{tabular}

Nilai tertinggi $=60 / 60 \times 100=100$

Keterangan :

$$
\begin{array}{lll}
\mathrm{A}=\text { Sangat baik } & \mathrm{B}=\text { Baik } & \mathrm{C}=\text { Cukup } \\
\mathrm{D}=\text { Kurang } & \mathrm{O}=\text { Tidak ada } &
\end{array}
$$

Dari data di atas menunjukkan bahwa nilai ideal ketersediaan yakni 75 masih jauh tercapai. SMP N 1 Bantul baru mencapai angka 45, sedangkan SMP IT Darul Hikmah Pakem mencapai angka 40, dan SMP N 19 Purworejo mencapai angka 
41,6. Dari data hasil wawancara guru dan kepala sekolah, penyebab belum optimalnya ketersediaan sarana Lab IPS di sekolah adalah bahwa pengembangan Lab IPS di sekolah masih relatif baru, tidak adanya keharusan ketersediaan Lab IPS di sekolah, sehingga dalam penyusunan program dan penyediaan dana pengembangan bukan prioritas utama. Para kepala sekolah menjelaskan bahwa keberadaan Lab IPS di sekolah sifatnya tidaklah wajib, sehingga untuk mengembangkan Lab IPS di sekolah diperlukan perjuangan untuk meyakinkan berbagai unsur di sekolah bahwa Lab IPS juga merupakan suatu hal yang sangat penting.

b. Manajemen organisasi

Manajemen organisasi Lab IPS setidaknya mengandung unsur Kepala Sekolah, Wakil Kepala Sekolah, Koordinator Laboratorium, Penanggung jawab Laboratorium, Laboran. Selama ini setiap sekolah telah memiliki Laboratorium, sehingga struktur organisasi telah siap sebagaimana diamanatkan peraturan pemerintah.

Kepala Lab di tiga sekolah telah memiliki sertifikat dari perguruan tinggi. Hanya saja yang menjadi kendala di kedua sekolah tersebut adalah ketersediaan laboran. Menurut peraturan pemerintah bahwa standar laboran adalah D3 sesuai bidangnya. Ketersediaan laboran tentu memerlukan anggaran tersendiri, sehingga ketiga sekolah belum memiliki laboran IPS. Sebagai strategi untuk mengintensifkan manajemen Lab IPS, ketiga sekolah melakukan koordinasi secara tim di antara para guru IPS di sekolah. Mereka melakukan rotasi sebagai kepala laboratorium dan laboran IPS. 


\section{c. Ketersediaan isi}

Laboratorium IPS yang ada di sekolah rata-rata memiliki koleksi yang masih sangat terbatas. Hal ini dimungkinkan karena kurangnya pendanaan terkait dengan pengadaan koleksi laboratorium IPS. Hal ini dapat dilihat dari belum tersedianya jaringan internet dan jaringan air dalam laboratorium IPS secara optimal. Padahal jaringan internet sangat diperlukan untuk mengakses materi pendukung pembelajaran IPS. Rata-rata jaringan listrik sudah ada dan dimanfaatkan untuk menghidupkan speaker, lampu dan peta tematik dengan simulasi lampu. Sedangkan jaringan internet di SMP N 1 Bantul dan SMP N 19 Purworejo telah terhubung melalui wifi yang kecepatannya sudah cukup baik, tetapi di SMP IT Darul Hikmah Pakem ketersediaan wifi masih kurang baik.

Benda koleksi yang ada di laboratorium IPS antara lain berupa globe, contoh-contoh batuan, kompas, peta tematik, peta gulung, alat pengukur curah hujan, alat peraga (siklus air; lapisan tanah; bentuk awan), gambar-gambar pahlawan, atlas Indonesia dan dunia, fosil, maket rumah tradisional, jenis uang, media pembelajaran IPS.Dari berbagai koleksi yang ada, terdapat beberapa koleksi yang sudah tidak layak dan memerlukan penggantian namun tidak ada tindak lanjutnya.

\section{Manajemen Laboratorium IPS di SMP}

a. Manajemen koleksi

Hasil observasi dan wawancara di ketiga sekolah menunjukkan bahwa manajemen koleksi Laboratorium IPS didasarkan pada pengelompokkan subjek atau konsep ilmu-ilmu sosial. Sebagai contoh untuk koleksi benda-benda dan peralatan terdapat tempat penyimpanan koleksi konsep sejarah, konsep ekonomi, konsep sosiologi, dan konsep geografi. 
b. Manajemen penggunaan

Manajemen penggunaan Lab IPS di ketiga sekolah telah diatur sedemikian rupa, sehingga memungkinkan pemanfaatan Lab secara teratur. Walaupun sudah terdapat jadwal penggunaan Lab IPS, tetapi ketiga sekolah belum memiliki jadwal teratur penggunaan Lab IPS setiap 1 semester. Ketiga sekolah masih menggunakan jadwal yang sifatnya insidental yang biasanya direncanakan dalam setiap bulan. Sebagai contoh untuk penggunaan Lab IPS pada bulan September, maka para guru IPS telah memesan jam penggunaan paling lambat tanggal 30 Agustus. Dengan demikian tidak akan terjadi benturan jadwal penggunaan antara guru IPS.

\section{Peran Kepala Sekolah dalam Pemanfaatan Laboratorium IPS}

Kepala Sekolah memiliki peran penting dalam upaya optimalisasi pemanfaatan laboratorium IPS. Kepala sekolah sebagai penentu kebijakan cukup mendukung pengembangan laboratorium IPS baik dari segi penyediaan fasilitas ruang yang representatif yang dapat menampung rombongan kelas maupun upaya rehabilitasi laboratoium. Berbagai upaya dilakukan untuk menambah koleksi laboratorium dengan mengusulkan pengadaan dari Kementrian Pendidikan Nasional. Salah satu bentuk dukungan dari kepala sekolah sebagai penentu kebijakan dalam pengembangan laboratorium IPS yaitu mengadakan pelatihan pengelolaan laboratorium bekerjasama dengan perguruan tinggi, MKKS dan MGMP IPS. Untuk memotivasi guru mata pelajaran IPS yang menjadi ketua laboratorium dengan dihargai sebanyak 12 jam pelajaran.

Namun dalam pelaksanaannya masih terdapat beberapa hambatan dalam pengembangan Laboratorium IPS terkait dengan kebijakan. Belum adanya aturan tertulis yang rinci tentang 
pengembangan Laboratorium IPS menyebabkan para pimpinan sekolah kesulitan menyusun program pengembangan Laboratorium. Permasalahan lain dalam pengembangan laboratorium adalah aspek pendanaan yang dibutuhkan yang sangat besar untuk memenuhi kebutuhan laboratorium IPS. Para kepala sekolah merasa berat untuk memenuhi pemenuhan Laboraorium IPS sebagaimana yang diidealkan karena jumlah anggaran yang besar, sehingga setiap sekolah memiliki strategi sama dalam pengembangan Laboratorium IPS yakni melalui strategi pemenuhan bertahap.

Pemenuhan standar Laboratorium IPS dalam pengadaan laboran juga menjadi kesulitan tersendiri bagi para kepala sekolah. Selain sulitnya menemukan laboran yang memiliki kompetensi dan kualifikasi Laboratorium IPS, konsekuensi finansial adanya laboran juga merupakan hambatan. Namun untuk sekolah yang memiliki kekuatan finansial tinggi seperti di SMP N 1 Bantul Kepala sekolah telah merencanakan merekrut laboran atau tenaga khusus laboratorium IPS.

Hasil wawancara kepada para kepala sekolah yang memiliki Laboratorium IPS menunjukkan bahwa perhatian mereka terhadap pengembangan Laboratorium IPS sudah baik. Hal ini dibuktikan dengan kebijakan mereka untuk mengembangkan kompetensi guru IPS melalui program pendidikan dan pelatihan kepala Laboratorium IPS. Bahkan SMP N 1 Bantul secara khusus telah memiliki kesepakatan pembimbingan pengembangan Laboratorium IPS dengan Prodi Pendidikan IPS FIS UNY. Hal demikian menunjukkan bahwa perhatian Kepala Sekolah terhadap Laboratorium IPS sudah baik, walaupun belum berhasil mencapai tahap seperti halnya Laboratorium lainnya (Bahasa dan IPA) yang perintisannya telah lama. Hal lain yang menjadi 
hambatan dalam pengelolaan laboratorium antara lain adalah kurangnya pemahaman laboratorium IPS terpadu yang ideal karena laboratorium IPS yang selama ini ada hanyalah laboratorium geografi, sejarah, dan ekonomi.

\section{Strategi Guru dalam Memanfaatkan Laboratorium IPS}

Selama ini pemanfaatan Laboratorium IPS masih terbatas untuk pelaksanaan kegiatan pembelajaran sesuai jadwal pelajaran. Belum ada kegiatan pemanfaatan Laboratorium di luar jam pelajaran. Salah satu penyebabnya menurut para guru adalah bahwa mereka masih kesulitan menyusun program kegiatan di luar jam pelajaran, karena untuk menyusun kegiatan di luar jam pelajaran mereka harus melakukan koordinasi dengan kegiatankegiatan lainnya.

Penyusunan jadwal kegiatan pembelajaran IPS di laboratorium biasanya disesuaikan dengan karakteristik materi pelajaran yang sedang dipelajari siswa. Karena itulah kegiatan pembelajaran di laboratorium IPS tidak dilakukan setiap pelajaran IPS. Sebagai contoh misalnya pada saat akan mempelajari masalah-masalah sosial di lingkungan sekitar, guru akan mengajak siswa ke dalam laboratorium. Untuk menampilkan secara visual dan berbagai benda yang berkaitan dengan masalahmasalah sosial tersebut guru dapat menghadirkan melalui pemutaran film dan menunjukkan benda-benda asli. Kondisi laboratorium yang dirancang untuk ruangan ideal menjadikan pembelajaran audio video menjadi lebih menarik dibanding disajikan di dalam ruangan kelas biasa.

Contoh lain kegiatan pembelajaran yang dilakukan di dalam Laboratorium IPS adalah melakukan praktik penjernihan air. Kegiatan ini akan lebih mudah dan praktis dilakukan di laboratorium karena tidak perlu memindahkan berbagai perangkat 
media dan peralatan yang cukup kompleks. Objek penelitian laboratorium IPS yang diteliti juga menunjukkan kepemilikan benda-benda asli yang lebih praktis dipelajari langsung di dalam laboratorium daripada di ruang kelas. Misalnya di laboratorium IPS SMP Darul Hikmah terdapat peraga peralatan kehidupan masa praaksara seperti fosil, kapak, dan sebagainya.

Guru IPS SMP masih belum optimal menggunakan laboratorium IPS dalam pembelajaran. Walaupun sudah ada penjadwalan setiap minggunya namun belum semua guru IPS memanfaatkan laboratorium IPS. Hal ini dikarenakan koleksi yang kurang lengkap dan koleksi yang sudah mengalami kerusakan. Laboratorium IPS juga masih parsial sehingga materi yang diajarkan di laboratorium IPS juga masih parsial dan didominasi materi geografi dan sejarah sesuai dengan koleksi yang ada di laboratorium yang kebanyakan alat bantu geografi dan sejarah. Faktor belum optimalnya penggunaan laboratorium IPS di sekolah adalah bahwa tidak semua guru IPS menguasai cara penggunaan Laboratorium IPS. Hal ini menyangkut dengan ketrampilan para guru menggunakan media pembelajaran seperti menggunakan peraga, percobaan, audio video, internet dan sebagainya. Kebiasaan sebagian guru menggunakan cara mengajar konvensional (ceramah) juga merupakan salah satu penyebab mereka tidak tertarik menggunakan Laboratorium IPS. Untuk memanfaatkan Laboratorium IPS dalam kegiatan pembelajaran tentu memerlukan perencanaan yang berbeda dengan pembelajaran di dalam kelas. Hal inilah yang terkadang membuat sebagian guru kurang optimal menggunakan lab untuk kegiatan pembelajaran.

Walaupun ketersediaan sarana dan koleksi laboratorium IPS yang masih sangat terbatas namun bagi guru sangat membantu 
dalam pelaksanaan pembelajaran IPS karena guru tidak perlu repot-repot membawa berbagai peralatan ke kelas namun cukup melaksanakan pembelajaran di laboratorium.

Demi meningkatkan pemahaman guru IPS mengenai laboratorium IPS, guru juga mengikuti berbagai pelatihan pengelolaan laboratorium yang diselenggarakan oleh perguruan tinggi.

Adanya laboratorium IPS juga membuat guru menjadi lebih kreatif dalam mengajar karena dilengkapi dengan alat peraga dan mampu membuat suasana pembelajaran yang berbeda dari pembelajaran yang biasa dilakukan di kelas.

\section{Pemanfaatan Laboratorium IPS Bagi Para Siswa}

Berbagai tanggapan muncul dari para siswa ketika ditanya mengenai pemanfaatan laboratorium IPS. Berkaitan dengan keberadaan laboratorium IPS, semua siswa menyatakan sangat senang dan tertarik belajar di laboratorium IPS. Mereka antusias saat mengikuti pembelajaran IPS di laboratorium karena dapat mempermudah memahami materi pembelajaran IPS, dapat melihat berbagai fenomena sosial melalui alat peraga dan media pembelajaran, dapat menggunakan alat dalam pembelajaran secara langsung sehingga memperkuat pemahaman siswa.

Dari wawancara para siswa di tiga sekolah diperoleh data bahwa semua siswa merasa keberadaan laboratorium IPS mampu mempermudah pemahaman mereka pada materi yang dipelajari. Para siswa mencontohkan misalnya materi tentang proses pembentukan bumi. Apabila di dalam kelas biasa media yang digunakan dalam pembelajaran sangat terbatas, di dalam laboratorium lebih lengkap dan bervariasi. Selain media audio visual, para siswa dapat melihat miniatur dan contoh-contoh benda nyata. 
Para siswa juga mengaku bahwa laboratorium dapat menghadirkan berbagai fenomena sosial di lingkungan tempat tinggal seperti bagaimana proses kerusakan lingkungan hidup, kegiatan jual beli di pasar, penyimpangan sosial, dan bangunanbangunan candi dapat dipelajari di dalam laboratorium IPS. Menurut para siswa di ketiga sekolah bahwa para guru sudah banyak yang menggunakan media audio visual di dalam kelas, tetapi kondisi pembelajaan di laboratorium lebih lengkap karena juga ditunjukkan berbagai specimen atau contoh benda-benda asli.

Di dalam laboratorium IPS para siswa juga sangat senang karena pembelajaran lebih nyata. Sebagai contoh para siswa diajari bagaimana teknik menjernihkan air secara sederhana, mengukur asam-basa tanah dengan media sederhana, percobaan jual beli, dan sebagainya. Diakui para siswa di ketiga sekolah, bahwa memang peralatan dan koleksi yang dimiliki laboratorium IPS di sekolah masih kurang, terutama peralatan dan koleksi yang berhubungan dengan percobaan dan benda nyata.

Tentang bagaimana pendapat siswa dari para guru yang menggunakan laboratorium IPS untuk pembelajaran, para siswa menjawab bervariasi. Menurut mereka, sebagian guru IPS ada yang belum optimal menggunakan laboratorium IPS.

Peralatan yang tersedia di laboratorium IPS sangat mendukung jalannya pembelajaran walaupun ketersediaannya masih kurang lengkap. Siswa merasa senang dan ada inovasi dalam pembelajaran saat dilakukan di laboratorium IPS. Guru sudah mampu menggunakan berbagai jenis peralatan yang ada di laboratorium IPS sehingga pembelajaran lebih menarik bagi siswa daripada dilakukan di kelas secara monoton. Di laboratorium IPS siswa dapat mengamati dan berperan serta langsung dalam 
kegiatan pembelajaran, sehingga dengan ikut andilnya siswa dalam setiap langkah-langkah pembelajaran menjadikan siswa menjadi lebih aktif dan penasaran untuk selalu mengikuti kegiatan pembelajaran.

\section{Pembahasan}

Berdasarkan kajian teori bahwa laboratorium IPS memiliki fungsi memberikan kelengkapan pelajaran teori, memberikan ketrampilan kerja ilmiah bagi siswa, menambah ketrampilan dalam menggunakan alat dan media, memupuk rasa ingin tahu siswa, dan membina rasa percaya diri, serta penemuan yang didapat dari proses kegiatan kerja di laboratorium. Berdasarkan data yang diperoleh dari ketiga sekolah, sebagian fungsi laboratorium seperti diungkap di atas telah terpenuhi, namun belum optimal.

Berdasarkan data dari guru, kepala sekolah, dan siswa fungsi laboratorium IPS sebagai cara untuk melengkapi pembelajaran teori telah mulai terlihat. Hal ini ditunjukkan strategi kepala sekolah dan guru dalam mengembangkan kegiatan pembelajaran dengan tujuan mengenalkan siswa pada upaya penerapan ilmu pengetahuan yang dipelajari. Pemenuhan sarana prasarana dan strategi pembelajaran simulasi, percobaan, dan praktik-praktik IPS menunjukkan pemanfaatan laboratorium IPS untuk melengkapi teori dalam mata pelajaran IPS mulai kelihatan.

Upaya pemberian ketrampilan usaha ilmiah siswa dalam laboratorium IPS memang sudah diupayakan oleh para guru di ketiga sekolah tersebut, hanya saja belum terstruktur sebagai tradisi kajian ilmiah. Hal ini dapat dimengerti, karena keterbatasan jumlah jam pelajaran yang tersedia. Selain itu bahwa ketiga laboratorium IPS yang dijadikan subjek penelitian baru berdiri selama dua tahun. Namun demikian para guru IPS dan 
Kepala Sekolah menunjukkan semangat dan niat mengembangkan fungsi laboratorium IPS secara optimal melalui pembaharuan perencanaan setiap tahun.

Hal menonjol dalam pemanfaatan laboratorium IPS di tiga sekolah yang diteliti adalah peningkatan ketrampilan siswa dalam menggunakan alat dan media dalam pembelajaran IPS. Sebagai contoh dengan adanya praktik-praktik pembelajaran dalam laboratorium IPS mereka dapat menggunakan alat peraga, praktik langsung kegiatan seperti simulasi jual beli, mengukur derajat asam-basa, menggunakan peta, dan sebagainya. Rasa ingin tahu siswa juga meningkat sangat baik dengan pendekatan pembelajaran inquiry di laboratorium IPS. Bahkan banyak siswa yang menyatakan sangat senang ketika belajar di laboratorium IPS. Menurut keterangan para guru IPS, anak-anak sering menanyakan kapan belajar di laboratorium IPS. Hal ini menandakan bahwa keberadaan laboratorium IPS benar-benar bermanfaat bagi peningkatan kualitas pembelajaran IPS.

Pemanfaatan laboratorium IPS sebagai proses penemuan memang belum optimal sebagaimana diidealkan. Semestinya memang laboratorium IPS mampu menjadi ajang latihan para siswa melakukan penelitian sederhana sebagai latihan berfikir ilmiah. Namun hal tersebut belum optimal dikarenakan oleh beberapa hal seperti belum terprogramnya waktu pemanfaatan laboratorium IPS secara sistematis, belum disiapkannya prosedur pemanfaatan laboratorium IPS secara lengkap, dan masalahmasalah sarana dan prasarana yang belum mendukung.

Berkaitan dengan menakisme pelayanan laboratorium IPS di tiga sekolah yang diteliti memiliki kesamaan kondisi yakni belum terprogramnya kegiatan laboratorium IPS di masing-masing sekolah,cara pengadministrasian isi laboratorium IPS belum 
terstandar, prosedur layanan laboratorium IPS juga belum tertata. Beberapa masalah di atas faktor utama penyebabnya adalah keberadaan sumber daya pengelola laboratorium IPS yang masih terbatas. Walaupun kepala laboratorium IPS telah memiliki sertifikat kepala laboratorium IPS yang dikeluarkan universitas, namun mereka masih mengalami kendala teknis dalam menerapkan standar prosedur pelayanan laboratorium IPS.

\section{Simpulan}

Berdasarkan hasil penelitian dan pembahasan yang telah diuraikan maka dapat ditarik kesimpulan sebagai berikut:

1. Kondisi laboratorium IPS di tiga sekolah yang diteliti pada dasarnya telah memenuhi syarat minimal laboratorium $7 \mathrm{~m} \mathrm{x}$ 7m. Hanya saja ketersediaan perangkat lain yang seharusnya ada dalam Laboratorium IPS masih kurang lengkap.

2. Manajemen laboratorium IPS didasarkan pada pengelompokkan subjek atau konsep ilmu-ilmu sosial serta penggunaan laboratorium IPS di ketiga sekolah telah diatur sedemikian rupa, sehingga memungkinkan pemanfaatan laboratorium secara teratur dan tidak terjadi benturan jadwal antar guru.

3. Kepala sekolah mulai menyadari pentingnya laboratorium IPS dalam mendukung kualitas pembelajaran di SMP, sehingga mereka mulai memperhatikan keberadaan laboratorium IPS dengan dukungan kebijakan pengembangan laboratorium IPS.

4. Guru merasakan pentingnya keberadaan laboratorium IPS, dan mereka telah berupaya melakukan pemanfaatan laboratorium IPS dalam mendukung pembelajaran IPS namun belum optimal disebabkan oleh terbatasnya sumber daya yang menangani, belum optimalnya dukungan finansial untuk mengembangkan laboratorium IPS dan pada kenyataannya bahwa keberadaan laboratorium IPS di SMP masih merupakan hal baru dalam 
praksis pendidikan IPS di sekolah.Para siswa merasa sangat terbantu dengan adanya laboratorium IPS di sekolah, karena pembelajaran menjadi lebih mudah dan menyenangkan.

\section{Saran}

Dalam rangka memberikan alternatif pemecahan terhadap pemanfaatan laboratorium IPS SMP terdapat beberapa hal yang perlu dilakukan antara lain:

1. Karena pentingnya landasan hukum bagi penyelenggara pendidikan, maka sangat tepat apabila keberadaaan laboratorium IPS dimasukkan dalam aturan tertulis standar sarana dan prasarana pendidikan dalam Standar Nasional Pendidikan.

2. Pemerintah dan masyarakat perlu aktif berperan serta meningkatkan kompetensi pengelola laboratorium IPS dan mendukung peningkatan kualitas isi laboratorium IPS.

\section{DAFTAR PUSTAKA}

Muhammad Numan Somantri. (2001). Menggagas Pembaharuan Pendidikan IPS. Bandung: Remaja Rosdakarya.

http://www.majalahpendidikan.com Diunduh pada hari Jumat tanggal 19 Oktober 2012 pukul 10.30 WIB

http://blog.tp.ac.id. Diunduh pada hari Jumat tanggal 19 Oktober 2012 Pukul 10.41 wib.

Mustafawan. (2012). Pengertian dan fungsi laboratorium. http://wanmustafa.wordpress.com. Diunduh pada hari Jumat tanggal 19 September 2012 pukul 8.53 wib

Sugiyono. (2011). Metode penelitian kuantitatif, kualitatif $\& R n D$. Bandung: Alfabeta. 